\title{
COVID-19 Responsive Village: The Importance of Involving Persons with Disabilities*
}

\author{
Dian Karinawati Imron, ${ }^{1 * *}$ Marthella Rivera Roidatua ${ }^{1}$ \\ ${ }^{1}$ Ministry of Villages, Development of Disadvantaged Regions and Transmigration \\ Republic of Indonesia, Jakarta - Indonesia
}

\begin{abstract}
Persons with disabilities deal with complex challenges during the COVID-19 pandemic, especially those who live in the villages. The pandemic situation has brought limitations for persons with disabilities to get proper services both in health and social assistance. The strict regulation during COVID-19 became challenging for rural villages. Persons with disabilities as vulnerable group is an essential part of inclusive development. This research aims to identify why involving persons with disabilities matters and analyze how rural villages implement inclusive development without 'leaving no one behind'. The method of the study is mixed-method. The result shows that involving persons with disabilities has a significant impact on village development during pandemics. The study concludes that it is important to manage inclusive management both in village development and space provision for the organizations working with persons with disabilities to accommodate the needs and empowerment of the persons with disabilities.
\end{abstract}

\begin{abstract}
Penyandang disabilitas menghadapi tantangan yang kompleks selama pandemi COVID-19, terutama yang tinggal di pedesaan. Situasi pandemi membatasi penyandang disabilitas untuk mendapatkan pelayanan yang layak baik di bidang kesehatan maupun aspek sosial. Peraturan ketat selama COVID-19 menjadi tantangan bagi penyandang disabilitas di desa. Penyandang disabilitas sebagai kelompok yang rentan merupakan bagian penting dari pembangunan inklusif. Penelitian ini bertujuan untuk mengidentifikasi pentingnya melibatkan penyandang disabilitas dalam pembangunan dan menganalisis bagaimana desa melaksanakan pembangunan inklusif tanpa 'meninggalkan siapa pun'. Metode penelitian menggunakan metode campuran. Metode mix-method dilaksanakan melalui dua tahap. Tahap pertama fokus pada aspek kuantitatif dan tahap kedua menganalisis temuan untuk kemudian menggali pemahaman yang mendalam tentang pembangunan inklusif. Temuan penelitian menggambarkan bahwa melibatkan penyandang disabilitas memiliki dampak yang signifikan terhadap pembangunan desa selama pandemi. Kesimpulan dari penelitian adalah pentingnya pengelolaan inklusif baik dalam pembangunan desa, penyediaan ruang bagi penyandang disabilitas maupun organisasi untuk mengaspirasikan kebutuhan kelompok dan upaya pemberdayaan penyandang disabilitas.
\end{abstract}

Keywords: inclusive development; persons with disabilities; village, pandemic; empowerment

\footnotetext{
*The original draft of this article has been presented on the 6th International Conference on Social and Political Sciences (ICOSAPS) 2020: "Strengthening Resilient Society in the Disruptive Era" at Universitas Sebelas Maret Surakarta, Indonesia. ${ }^{* *}$ Corresponding Author: Dian Karinawati Imron (dian.karinawati@kemendesa.go.id), Jl. TMP Kalibata No. 17, Jakarta Selatan,12750, DKI Jakarta, Indonesia.
} 


\section{Introduction}

The COVID-19 pandemic has a profound impact on persons with disabilities (PwD). The regulation regarding physical distancing and large-scale social restriction limit the mobility of persons with disabilities (Leocani et al. 2020; Peters 2020). These rules have changed persons with disabilities' lives in health, social live, and economy. Aspects of the health of persons with disabilities such as diabetes, heart problems, respiratory problems, and lower immunity levels make persons with disabilities more susceptible to exposure to COVID-19 (WHO 2020a). This fact shows how people with disabilities are at a high risk during a pandemic (Kavanagh et al. 2020; UNHR 2020). World Health Organization (2020b) revealed the enormous risk of being exposed to COVID-19 for persons with disabilities in relation to congenital medical conditions, barriers to implementing health protocols, and various accessibility.

There are approximately 37.1 million persons with disabilities in Indonesia. Regulation Number 8 the Year 2016 regarding persons with disabilities states that persons with disabilities have a right to safety and security in disaster situations. This regulation explains that persons with disabilities have the right to access information, gain knowledge in disaster risk reduction, be evacuated when necessary, and get proper facilities. In addition, Regulation number 6 Year 2014, especially Article 20 concerning local village authority, also gives power for the villagers to make decisions for handling disasters due to conditions for persons with disabilities. However, the strict regulation during the COVID19 pandemic has made the situation more challenging for rural villages that generally have a low quality of health facilitation, economic strain, and social barrier (Aulia, Siti Asiah, and Irfan 2021; Ndaumanu 2020). Persons with disabilities who live in villages have limited access to information, such as accessing the internet and transportation due to geographic conditions, poor human resource management, and underdeveloped governance (Peters 2020).

Persons with disabilities in these villages deal with the uncertainty of quality sanitation and difficulty to practice standardized health protocols (Sakellariou, Malfitano, and Rotarou 2020). People with special disabilities require different accommodations. These people include those with intellectual disabilities, persons with disabilities who need therapy, and blind and deaf people. People with intellectual disabilities and severe disabilities need a companion in their daily life and therapy (Leocani et al. 2020). Large-scale social restrictions restrain persons with disabilities from obtaining health facilities because of the public transportation restriction regulation. Blind citizens rely on touches when doing their activities. This condition would position persons with disabilities in a vulnerable situation (Lebrasseur et al. 2021). Persons with physical disabilities that use crutches and wheelchairs also need assistance to maintain their clean equipment, such as with disinfectants. Also, deaf people require a Sign Language interpreter for information accessibility. People with the different types of disabilities require different accommodations to be fulfilled.

The COVID-19 responsive village program is a program in which the village officials are required to provide equal assistance for all villagers. However, persons with disabilities are 
neglected in government criteria and political participation (Aulia et al. 2021; Febriantanto 2019). The challenge also occurs from the budget allocation and legal support from government (Irawan 2017; Pudyatmoko and Dewi 2017). Moreover, the impact of the pandemic on persons with disabilities linked to employment and living income (Tan and Ramadhani 2020; Widjaja, Wijayanti, and Yulistyaputri 2020). The local government generally has less understanding about the accommodations of persons with disabilities during a pandemic. The government regulation, for instance, does not specifically state persons with disabilities as beneficiaries of government assistance. This study aims to identify why involving persons with disabilities matters and analyze how rural villages implement inclusive development. The study explores the various practices and actions to address the problem. Furthermore, the study develops strategies to encourage inclusive village development during the COVID-19 pandemic.

\section{Disaster Management for Persons with Disabilities}

Disaster management for persons with disabilities (PwD) has been developed over several decades. There is a growing concern of disability-inclusive disaster management and began with the exclusion issues of persons with disabilities (Santoso, Noor, and Ulum 2013). Research findings indicate that persons with disabilities are often neglected within disaster management policy and government programs (Pertiwi, Llewellyn, and Villeneuve 2020). The main reason for this is poor understanding and low interactions with persons with disabilities.
Also, social barriers become more challenging if the social environment of persons with disabilities has low less awareness and negative attitude towards persons with disabilities.

The Sendai Framework for Disaster Risk Reduction conveys seven targets and four priorities in disaster risks management: 1) Understanding disaster risk. 2) Strengthening disaster risk governance to manage disaster risk. 3) Investing in disaster reduction for resilience. 4) Enhancing disaster preparedness for effective response and "Build Back Better" in recovery, rehabilitation, and reconstruction.

One of the four priority states that the disaster management includes women and persons with disabilities. Persons with disabilities and their organizations play critical roles in designing and implementing disaster risk programs with a universal approach (UNDRR 2015).

The Indonesian legal framework has integrated persons with disabilities into disaster management risk. From the national level to the local level, government generally has established documents of Disaster Risk Reduction and explicitly mentioned "disability". The framework includes persons with disabilities as one of the socially vulnerable groups (Pertiwi et al. 2020). Involving PwD in disaster risk reduction can be done by providing accessible technology and information for vulnerable populations. The innovations of technology are integrated into devices, hearing aids, Braille, and wheelchairs (Stough and Kang 2015)

The government has ratified the Convention on the Rights of Persons with Disabilities. The 
regulation states that persons with disabilities have the right to be included in disaster management. The next regulation is Regulation Number 8 Year 2016 regarding persons with disabilities. This regulation provides comprehensive actions where persons with disabilities have the right to be protected from disaster impacts. These rights include access to information, knowledge, and facilities (Lestari, Sumarto, and Isdaryanto 2017; McAuliff et al. 2014; Radissa et al. 2020).

\section{Inclusive Development}

The shifting paradigm in the 21st-century concerns the sustainable and inclusive development that needs to be implemented. The disability-inclusive development appears as a significant action made by the Government and stakeholder, which is aimed to "leave no one behind" in the whole aspect of development (Gupta, Pouw, and Ros-Tonen 2015). Inclusive development refers to the access and the allocation of resources managed and afforded by all people (Pouw and Gupta 2017). Inclusive development is interpreted as development processes that are inclusive and accessible for diverse needs and characters (Gutama and Widiyahseno 2020). It requires all persons to have equal access to education, health services, employment, and social supports. The relational perspective establishes the practice for inclusive development through: a) constructing communities of practice into disability awareness, b) strengthening responsive governance to enable empowerment, and c) being committed to inclusive development policy (Gupta et al. 2015).

The inclusive development raises awareness among government officials at the local level in the villages. The emerging concept initiates inclusive village development to increase persons with disabilities' participation in the development process (Pouw and Gupta 2017). The shift of cognition moves from a charity based on rights (Probosiwi 2017). The inclusive village does not privately refer to persons with disabilities and other groups that have been marginalized. Furthermore, inclusive development encourages different groups' appreciation to make positive contributions to village development (Gutama and Widiyahseno 2020). The inclusive development process conducted with the Twin-Track Approach is a useful tool (United Nations 2016). The twin-track approach integrates persons with disabilities and organizations working with them into the development process and provides community empowerment space.

The study uses a mixed method. This method involves an approach to create a combination of qualitative and quantitative data (Creswell and Clark 2017). The mixed-method is implemented through two stages. The first stage is focused to gather the quantitative data and create general conclusions. The quantitative aspect is aimed to identify aspect of inclusive village development. The second stage analyzes the first stage to get a more in-depth understanding of inclusive village development. The sample consists of 30 villages from 5 regions (regencies) in Indonesia namely Sukoharjo, Central Java, Bantul and Kulon Progo, Special Region of Yogyakarta, Situbondo, East Java and Bulukumba, South Sulawesi. The qualitative aspect aims to investigate each village's approach in facilitating inclusive development during the pandemic. In addition, 
the data from the research are gathered through interviews, questionnaire, and documentation. This method helps reveal the activity of the qualitative data analysis which is the subsequent phase after the quantitative data analysis.

\section{Why Does Involving Persons with Disabilities Matter?}

COVID-19 Responsive Village is a policy that positions a village as a subject to manage the prevention and address the impact of the pandemic in the village. The program is one of the government's programs to prompt village development during the pandemic. The Minister of Village's regulation number 8 Year 2020 regarding Priorities in Using Village Funds has become the legal framework to implement COVID-19 responsive village program. A village forms and assign a task force, whose members are volunteering villagers, to carry out actions to deal with the pandemic. The prevention program starts with socialization and education about the pandemic, food provision, handsanitizer, disinfectant, and instructions to stay at home. The government also handles COVID-19 by providing assistance for communities. The government has several schemes to support the village communities: social safety net, unemployment assistance, and food subsidy. However, various assistance programs have not been reached out optimally by the persons with disability in these villages. The COVID-19 responsive village has proven that villages have different challenges in accommodating persons with disabilities.

Involving persons with disabilities into development has been done since UN CRPD (Convention on the Rights of Persons with
Disabilities) was ratified by the Indonesian government. Nevertheless, regulations regarding this cannot be implemented in rural villages comprehensively. The situation shows that the issues of persons with disabilities have to correspond with local governance and development. There are important reasons beyond why involving persons with disabilities matters for both COVID-19 responsive village program and further inclusive village development:

\section{Increasing "Leave no One Behind" Awareness}

The understanding of "leave no one behind" should become a collective movement within the society. The "leave no one behind" movement is not merely a slogan but also an aspiration to create a quality environment. The ideal situation is when the society appreciates diversity regardless of anyone's physical, social, and economic backgrounds. Persons with disabilities are presented as one of marginalized groups. Persons with disabilities are still excluded in the society. Persons with disabilities face discriminations and a stigma (negative stereotype), and they have difficulties accessing basic services. The significant aspect especially concerns about the rights of persons with disabilities, for instance: in education, health, and legal protections.

The local governments in certain villages reveal that persons with disabilities lack access to information, legal documents, education, and health services. Persons with disabilities who generally work in the informal sector have lost their livelihoods due to the pandemic. Several local governments still comprehend the disability issues in conventional mindset and 
understanding that persons with disabilities do not have any ability to work and interact with the society.

The local governments' lack of understanding has implicated the poor quality in handling the issues of persons with disabilities during the pandemic. The awareness to encourage every person to participate fully in the society should be shared and attained within village communities especially during pandemic situations.

\section{Enhancing Perspective of Inclusive Development}

The discussion about inclusive development prompts diverse actors to take a part in the disability responsive development in the villages. Working with persons with disabilities in the village development program has had a big impact on changing many actors' perspective on inclusive development. Persons with disabilities have limited space to fulfill their needs in the development process. The voice of persons with disabilities is rarely heard in village forums. The low participation of persons with disabilities in the village development implicates the lack understanding of diverse actors in the villages, such as local governments, nongovernment organizations, and private actors. This situation has become a barrier for the diverse actors to understand the condition of persons with disabilities.

The COVID-19 situation in the villages shows that the village government does not yet understand the different conditions of persons with disabilities. Disability conditions are divided into four types of disabilities: physical, sensory, intellectual, and mental disability. The village government does not yet comprehend various disabilities in a holistic perspective. The situation affects the effectiveness of appropriate assistance for the four types of disability. Some villages do not have an approach for persons with intellectual disabilities who need a special avenue to provide information about COVID-19. These persons require repeated explanations of any information regarding COVID-19, and this should be done through a special communication approach. People with sensory disabilities, such as deaf people, require access to information in the form of sign language. Blind community needs to access information in form of audio. Persons with physical disabilities use tools, such as a wheelchair or crutches that need hygiene maintenance. The pandemic situation challenges the local government to accommodate accessibilities for people with different disabilities.

The COVID-19 situation in the village shows that the village government does not yet understand the types condition of persons with disabilities. Disability conditions are divided into 4 (four) types of disabilities: physical, sensory, intellectual, and mental. The village government does not yet comprehend various disabilities as holistic perspective. The situation affects the effectiveness of appropriate assistance for the type of disability. Some villages did not have an approach for intellectual disabilities that need a special way to provide socialization of COVID- 19 . Intellectual disabilities require a special approach where the government should provide regular socialization to increase the persons with disabilities and families understanding the COVID-19. Sensory disabilities such as the Deaf 
community requires access to information in the form of sign language. The Deaf community needs information access such as sign language interpreter or running text in television. Blind community needs information in audio form. Physical disabilities use tools such as wheelchair and crutch that need hygiene control. The pandemic situation challenges the local government to accommodate various disabilities accessibility.

Persons with disabilities are neglected in the local governments' programs and assistance. The central government's instruction to allocate the direct cash assistance from the village fund program (Bantuan Langsung Tunai Dana Desa) for vulnerable communities is interpreted differently in different villages. Some village governments do not categorize persons with disabilities as vulnerable groups. There are also persons with disabilities who do not receive assistance because they do not have valid national identity document or card. This problem links to the data availability. The local governments mostly do not have disaggregated data of persons with disabilities. The disaggregated data play important roles in mapping the different conditions of persons with disabilities and developing effective interventions.

The organization of PwD play roles in supporting PwD in the village to aware of the PwD challenges. The Indonesian Association of Women with Disabilities South Sulawesi said, "We established Self Help Group as a media to mainstreaming disabilities issues, finding a solution and strengthened Person with Disabilities especially those in the rural villages. The situation today is that the PwD did not fully aware about the disability issues. The access to information about disability issues is very minimal. We advocate PwD to gain knowledge and understanding about disabilities issue so that they can building communication to village government and communities and participate to the village development." The inclusive development perspective is comprised of infrastructures, social integration, budget supports, regulation, and engagement with persons with disabilities. Involving persons with disabilities have a significant impact on the encouragement of the local government perspective. These villages have an authority to design development planning with the inclusive perspective. Moreover, the inclusive governance will enhance the inclusive society.

\section{Cooperation with the Persons with Disabilities Organizations}

The cooperation with the persons with disabilities organizations manifests in broad benefits. This is a medium for these people to gain knowledge, learn skills, and make relationships to establish common goals. Persons with disabilities organizations have helped many village governments to provide services for persons with disabilities. Persons with disabilities organizations provide advocacy and voice the needs of persons with disabilities. These organizations have a better understanding and good communication approaches with persons with disabilities. The approach used by these organizations draw the attentions from persons with disabilities. The natural situation indirectly drives persons with disabilities to be willing to learn, thus increasing their capacity. Competencies, such as leadership, 
public speaking, social mapping, and group discussion have improved the skills of persons with disabilities.

Persons with disabilities organizations also develop wide networks connecting persons with disabilities, other organizations, and governments. The engagement of persons with disabilities in the village communities has supported the existence of inclusive regulations and policies. Organizations of persons with disabilities understand the barriers and vulnerable conditions of persons with disabilities. Therefore, cooperation with organizations of persons with disabilities sustains the development programs. The various regions that have successfully facilitated inclusive development programs generally collaborate with persons with disabilities organizations.

The organizations of persons with disabilities from the research location indicate that the organization actively participate in the village development. The organization generally built wide coordination and cooperation to government, academic sector and community. The organizations are Jaringan Disabilitas Indonesia, Perkumpulan SEHATI Sukoharjo, HWDI Sulawesi Selatan, PPDI Situbondo, Komunitas Disabilitas Desa Situbondo, Relawan Desa Panggungharjo Tanggap COVID-19, PerDik dan SIGAB. The organization do kinds of action. The first, significant role of organizations are advocation of persons with disabilities. Next, the roles of communication into the family level of persons with disabilities. The organizations describe that the communication approach to persons with disabilities should involving the family group.

\section{Practices of Inclusive Development during the Pandemic}

The practices of inclusive development in the villages are various and depend on each village's characteristics, the government's perspective, and social inclusion situation. The research has captured the aspects of inclusive development activities from 30 villages in five regencies. Eight aspects have been captures in the villages: 1) Infrastructure. 2) Accessibility of Information and Communication. 3) Regulation/policy. 4) Budget allocation. 5) Space for participation in village development. 6) Engagement of persons with disabilities. 7) Social inclusivity. 8) Organizations.

Figure 1 shows the aspects of inclusive development in the thirty villages. The aspect with the highest rate is aspect organization, and it is organizations of persons with disabilities in the villages. Eighty percent of the villages have organizations of persons with disabilities at the village level. Aspect social inclusivity indicates the social inclusivity that is $73 \%$. It links to the openness and supports of the villages' community for inclusive environment. The third, aspect space for participation in village development, represents the space for participation in the village development. Sixtyseven percent of villages have encouraged the participations of persons with disabilities. Aspect infrastructure shows the same percentage, which is $67 \%$, showing the number of villages that have provided accessible infrastructures. These infrastructures generally refer to village office infrastructures, such as ramps and restrooms for persons with disabilities. The aspect accessibility of information and communication shows about accessibility of information and communication in the village. 


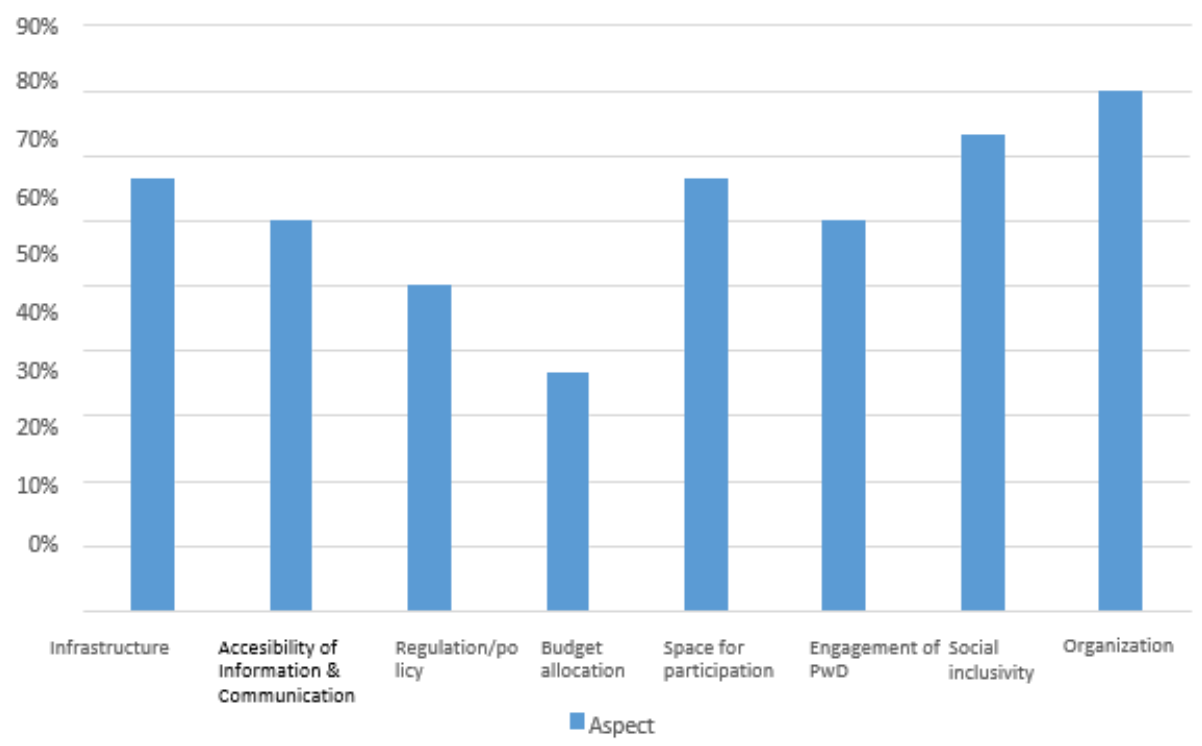

Figure 1

Aspect of Inclusive Development

The aspect accessibility of information and communication describe how persons with disabilities obtain access about government information linked to village development and the communication pattern to government.

The aspect regulation/policy shows about the regulation or policy that support PwD. The regulation can be provided from region government to village level government. In some village like Sukoharjo Region, government has supported inclusive development through regulation number 3 Year 2019. The regulation uses the Inclusion Village terminology as the village framework of development.

The aspect regulation/policy indicate the $50 \%$ village that implement inclusive development has regulation or policy. The regulation integrated to the village program and designed from the village planning document. The lowest aspect is aspect budget allocation that describes about budget support for PwD needs and activities. The aspect budget allocation shows that the budget allocation became the challenge of inclusive development in the village. The village government with regulation or policy about inclusive development generally provides budget allocation for inclusive program and accessibility for persons with disabilities. The budget allocation mechanism implements through village discussion and village forum (Musyawarah Desa). The participation of persons with disabilities in the village discussion determine the budget support of inclusive program in the village.

The innovative practices occur in the following villages and districts in Indonesia. The experience from villages to encourage inclusive development in line with handling COVID-19 for persons with disabilities. 


\section{Panggungharjo Village, Yogyakarta}

Panggungharjo Village, located in Bantul, Special Region of Yogyakarta, began inclusive development in 2016. The local government drives persons with disabilities and organizations to participate in village programs. Panggungharjo Village is one of the villages that establish a fast response program in managing COVID-19. Panggungharjo Village developed the Panggungharjo Responsive COVID-19 Program. The program comprehensively arranges a special task force to manage the impact of the pandemic in the village. The task force involved the local government and community working together through various actions. First, the role of Panggungharjo Responsive COVID-19 is a prevention structure. The structure implements socialization, education, and supporting health assistance for the community. Second, the role of Panggungharjo Responsive COVID-19 is coordination and handling pandemic activities in the village. Third, Panggungharjo Responsive COVID-19 builds databases and information and communication services integrated to village websites. The database monitors citizens at several levels and provides suggestions that need to be taken. The low levels, for example, monitoring of citizens who do not have symptoms of COVID-19. The citizens are expected to stay at home and apply health protocols. Next, the higher level where citizens have a high level of mobility and migrant citizens from exposed locations of COVID-19 or proven to be exposed. The citizens are expected to do self-quarantine for 14 days.

The excellence of Panggungharjo Responsive COVID-19 is that the village government has provided disaggregated data for persons with disabilities that are continuously updated. In the village website platform, the village government provides features for handling COVID-19. There is a report feature that supports activities and a feature to check the citizen's health. The Government also provides a hotline service for the community. Databases and services to the personal level are beneficial for persons with disabilities. Village governments can monitor people with disabilities in real-time.

Furthermore, Panggungharjo Responsive COVID-19 involved persons with disabilities as members of the Village Volunteer Against COVID-19. The participation of persons with disabilities is even given the task of managing the COVID-19 Stage Module's graphic design. Furthermore, the village government initiated pasardesa.id to help the community's economic environment through ICT (Information and Communication Technology). Pasardesa.id is an innovative aspect where people with disabilities have an economic opportunity to participate.

The local government effort to enhance policy about persons with disabilities through several program. The local government implement program within the Bantul Region Regulation number 11 the Year 2015 about Fulfilling the Rights of Persons with Disabilities. The local government implements vocational training, provides budget support, and encourages small and medium enterprises activity for persons with disability. The government maintains cooperation and collaboration with persons with disabilities organization both in village level and regional level. The collaboration with the organization has broaden the understanding of local government. The organization became the media for persons with disabilities 
to gain leadership and organizational capacity. The interaction of organization in the village is increasing persons with disabilities participation in village development forum. The persons with disabilities actively engage in village program.

\section{Sukoharjo Region, Central Java}

Sukoharjo Region began to develop inclusive village with the regional goverment regulation number 3 Year 2020 about inclusive village. The regulation clearly states the inclusive village as terminology to support inclusive village development. The regulation mention principle and the indicator of inclusive village. There are 5 (five) indicator for inclusive village: a) has a comprehensive monograph involving a disaggregated database of marginalized communities; b) institutionalization of marginal community organizations and Community Based Rehabilitation (RBM); c) understanding of marginalized communities and community responsibility to participate in protecting the rights of marginalized communities; d) involvement of marginalized communities in the overall development process; e) development of accessible infrastructure for basic services that are friendly to marginalized communities.

The regulation has a significant impact to provide direction and sustainability of inclusive development program. Sukoharjo is developing inclusive villages in 70 villages. The program encouraged by the persons with disabilities organization namely SEHATI Sukoharjo. The organization has support persons with disabilities in the villages through kinds of programs. The SEHATI organization provide basic understanding, promotion and advocacy for persons with disabilities, government and other organization in Sukoharjo. The organization establish Sanggar Inklusi Permata Hati (Inclusion Studio) in 12 districts. The inclusion studio provides access to health and education services for persons with disabilities and family.

The activity of organization during pandemic is the SEHATI Sukoharjo established a Task Force for Elderly, Vulnerable, and Persons with Disability for COVID-19 response at the district level, which monitors 150 villages and 17 subdistricts. SEHATI Sukoharjo provides socialization according to the health protocol in a convenient approach for persons with disabilities. The organization develops collaboration with companies related to corporate social responsibility programs. The private sectors are ASB, PT Guljati, and PT Sritex, assisting in necessities and handwashing facilities in the village. SEHATI also took the initiative to replace the plastic distribution to a cloth bag containing COVID-19 information.

\section{Bulukumba Region, South Sulawesi}

The government supports persons with disabilities in development by issuing regional regulations number 2 the Year 2018 about Protection and Services for Persons with Disabilities. The government has maintained the relations with organizations supporting persons with disabilities namely PerDIK (Pergerakan Difabel Indonesia untuk Kesetaraan). Organizations play an important role in advocating for of persons with disabilities' needs and rights. In Bulukumba there are 14 villages that are encouraged to become inclusive villages. The village government, organization of persons with disabilities, and organizations that support persons with disabilities have cooperated to 
provide assistance. The preparation activity for instance, a) held regular discussion that involved persons with disabilities and village government, b) increasing knowledge about of persons with disabilities issues and needs, c) village government capacity building training, d) gaining power of persons with disabilities to engage in village forum and e) encourage social inclusivity in village community.

The pandemic situation broader government awareness of marginalized group involving persons with disabilities. The Government of Bulukumba positioned persons with disabilities as an indicator of government assistance beneficiaries. The Government initiates aids and programs inclusively for vulnerable groups. The Government also organizes Public Safety Center in collaboration with sub-district and village posts to get reports of people who have a history of interacting with positive people with COVID19. Furthermore, there is a hotline to accommodate the Village Fund's distribution information of direct cast assistance. The Government initiated to assist effectively, not redundant, and targeted, involving providing equal access to persons with disabilities.

\section{The Inclusive Village Development}

Persons with disabilities are still generally absent from basic demographic data. This situation positions persons with disabilities with a lack of legal documents, such as national identity cards and administration documents. This has an impact on the fulfillment of persons with disabilities' rights and involvement in the development. The government's assistance sometimes misses persons with disabilities. In the development framework, the marginali- zation of vulnerable groups creates a gap in social and economic opportunities.

Data play a significant role in enabling the development process. The Government and other stakeholders can establish accurate assistance and services through such data. Disabilityinclusive development means ensuring that all phases of the development cycle consisting of design, budgeting, implementation, monitoring, and evaluation include a disability dimension. Persons with disabilities meaningfully and effectively participate in the development processes and policies (United Nations 2016). The disability-inclusive development should ensure that every person, regardless of ethnicity, gender, geography, disability, race, or status, possesses universal human rights.

The data about persons with disability in the village are an important element to enhance the responsive and inclusive program for persons with disabilities. The significance of the data is the disaggregated data of persons with disabilities. The data will show the actual situations of the persons with disabilities with information about their genders and ages. The government program will be precisely targeted if it is based on the disaggregated data. Finally, data consolidation of persons with disabilities between the Village Information System (SID) and the data in the Social Service Office is made to create disaggregated data of persons with disabilities in the villages. There is also a need to coordinate with disability communities/ organizations in regions with a network or members in the villages. Furthermore, the inclusive development needs to be established with Inclusive planning. The inclusive planning 
means the participation of persons with disabilities and organizations in village forums and planning development. In addition, the government has to take further steps beyond the development, and this is empowerment. Involving persons with disabilities in the development program requires engagement of persons with disabilities and their organizations. The empowerment programs are positive activities as they promote the increase of wellbeing in several aspects, such as economic, social, and cultural.

The appropriate approach to encourage inclusive village development is a Twin-Track approach (United Nations 2016). The approach involving persons with disabilities in development is alongside the empowerment program. The program specifically targets persons with disabilities and enable them to participate in the development programs. Persons with disabilities are the subjects who receive benefits from the programs. The program initiative should link to employment, vocational education and training, and equal opportunities to open or start a business.

\section{Conclusion}

The issue of involving persons with disabilities in inclusive village development is a necessity. The current COVID-19 pandemic situation shows that the COVID-19 responsive villages program should facilitate and accommodate persons with disabilities.

Although there are complex challenges in relation to accessibility, policy, and social situation, there are villages that are trying to provide inclusive assistance for persons with disabilities. Several villages also encourage systemic inclusive development through village governance and increasing participations of persons with disabilities in the village program. The occurrence of the pandemic is a momentum to build an inclusive village. Inclusive village development can be facilitated using a twintrack approach. This approach involves two strategies, the first of which is actively involving persons with disabilities in the development planning and programs. The second strategy is encouraging empowerment and engagement of persons with disabilities through different types of actions. Persons with disabilities and their organizations are positioned as the subjects within these strategies.

\section{Authorship and Contributions}

Marthella Rivera Roidatua and Dian Karinawati Imron are the main authors. Marthella Rivera Roidatua and Dian Karinawati Imron provided equal contributions to the design and implementation of the research, the analysis of the findings, and the writing of the manuscript.]

\section{References}

Aulia, Fara Dhania, Dessy Hasanah Siti Asiah, and Maulana Irfan. 2021. "Peran Pemerintah dalam Penanganan Dampak Pandemi COVID-19 bagi Penyandang Disabilitas." Prosiding Penelitian dan Pengabdian kepada Masyarakat 7(3):489. doi: 10.24198/ jppm.v7i3.29137.

Creswell, John W., and Vicki L. Plano Clark. 2017. Designing and Conducting Mixed Methods Research. 3rd ed. California: SAGE Publishing.

Febriantanto, Pangky. 2019. "Analisis Faktor Determinan Peningkatan Partisipasi Po- 
litik Penyandang Disabilitas pada Pilkada Kota Yogyakarta 2017." Jurnal PolGov 1(1):157. doi: 10.22146/polgov.v1i1. 48859.

Gupta, Joyeeta, Nicky R. M. Pouw, and Mirjam A. F. Ros-Tonen. 2015. "Towards an Elaborated Theory of Inclusive Development." European Journal of Development Research 27(4):541-59. doi: 10.1057/ ejdr.2015.30.

Gutama, Prima Putra Budi, and Bambang Widiyahseno. 2020. "Inklusi Sosial dalam Pembangunan Desa." Reformasi 10(1):7080. doi: 10.33366/rfr.v10i1.1834.

Irawan, Andrie. 2017. "Peranan Pemerintah Daerah Istimewa Yogyakarta dalam Perlindungan Hukum terhadap Perempuan Penyandang Disabilitas Korban Kekerasan." Jurnal Ilmiah Hukum De'Jure 2(2):202-17.

Kavanagh, Anne, Helen Dickinson, Gemma Carey, Gwynnyth Llewellyn, Eric Emerson, George Disney, and Chris Hatton. 2020. "Improving Health Care for Disabled People in COVID19 and beyond: Lessons from Australia and England." Disability and Health Journal. doi: 10.1016/j.dhjo.2020. 101050.

Lebrasseur, Audrey, Noémie Fortin-Bédard, Josiane Lettre, Eve Line Bussières, Krista Best, Normand Boucher, Mathieu Hotton, Simon Beaulieu-Bonneau, Catherine Mercier, Marie Eve Lamontagne, and François Routhier. 2021. "Impact of COVID-19 on People with Physical Disabilities: A Rapid Review." Disability and Health Journal 14(1). doi: 10.1016/j.dhjo.2020.101014.

Leocani, L., K. Diserens, M. Moccia, and C. Caltagirone. 2020. "Disability through COVID-19 Pandemic: Neurorehabilitation Cannot Wait." European Journal of Neurology 27(9):e50-51. doi: 10.1111/ ene.14320.
Lestari, Eta Yuni, Slamet Sumarto, and Noorochmat Isdaryanto. 2017. "Pemenuhan Hak bagi Penyandang Disabilitas di Kabupaten Semarang melalui Implementasi Convention on the Rights of Persons With Disabillities (CPRD) dalam Bidang Pendidikan." Integralistik 28(1):1-9. doi: 10.15294/integralistik.v28i1.11804.

McAuliff, Kathleen, Judah J. Viola, Christopher B. Keys, Lindsey T. Back, Amber E. Williams, and Crystal N. Steltenpohl. 2014. "Empowered and Disempowered Voices of Low-Income People with Disabilities on the Initiation of Government-Funded, Managed Health Care." Psychosocial Intervention 23(2):115-23. doi: 10.1016/j.psi.2014.07. 003.

Ndaumanu, Frichy. 2020. "Hak Penyandang Disabilitas: Antara Tanggung Jawab dan Pelaksanaan oleh Pemerintah Daerah." Jurnal HAM 11(1):131-50. doi: 10.30641/ ham.2020.11.131-150.

Pertiwi, Pradytia, Gwynnyth Llewellyn, and Michelle Villeneuve. 2020. "Disability Representation in Indonesian Disaster Risk Reduction Regulatory Frameworks." International Journal of Disaster Risk Reduction 45:101454. doi: 10.1016/j.ijdrr.2019. 101454.

Peters, David J. 2020. “Community Susceptibility and Resiliency to COVID-19 Across the Rural-Urban Continuum in the United States." The Journal of Rural Health 36(3):446-56. doi: 10.1111/jrh.12477.

Pouw, Nicky, and Joyeeta Gupta. 2017. "Inclusive Development: A Multi-disciplinary Approach." Current Opinion in Environmental Sustainability 24:104-8. doi: 10.1016/ j.cosust.2016.11.013.

Probosiwi, Ratih. 2017. "Desa Inklusi sebagai Perwujudan Pembangunan Berkelanjutan bagi Penyandang Disabilitas." Media Informasi Penelitian Kesejahteraan Sosial 41(3): 217-28. doi: 10.31105/mipks.v41i3.2255. 
Pudyatmoko, Y. Sri, and Imma Indra Dewi. 2017. "Penganggaran Keuangan Daerah yang Berpihak pada Pemenuhan Hak-Hak Penyandang Disabilitas di Kota Surakarta." Mimbar Hukum 29(1):31-42. doi: 10.22146/jmh.17643.

Radissa, Vanaja Syifa, Hery Wibowo, Sahadi Humaedi, and Maulana Irfan. 2020. "Pemenuhan Kebutuhan Dasar Penyandang Disabilitas pada Masa Pandemi COVID-19." Focus: Jurnal Pekerjaan Sosial 3(1):61-69. doi: 10.24198/focus.v3i1.28735.

Sakellariou, Dikaios, Ana Paula Serrata Malfitano, and Elena S. Rotarou. 2020. "Disability Inclusiveness of Government Responses to COVID-19 in South America: A Framework Analysis Study." International Journal for Equity in Health 19(1):131. doi: 10.1186/s12939-020-01244-X.

Santoso, Anang Dwi, Irwan Noor, and Mochamad Chazienul Ulum. 2013. "Disabilitas dan Bencana (Studi tentang Agenda Setting Kebijakan Pengurangan Risiko Bencana Inklusif bagi Penyandang Disabilitas di Kabupaten Klaten, Jawa Tengah, Indonesia)." Adiministrasi Publik 3(12): 2033-39.

Stough, Laura M., and Donghyun Kang. 2015. “The Sendai Framework for Disaster Risk Reduction and Persons with Disabilities." International Journal of Disaster Risk Science 6(2):140-49. doi: 10.1007/s13753-0150051-8.

Tan, Winsherly, and Dyah Putri Ramadhani. 2020. "Pemenuhan Hak Bekerja bagi Penyandang Disabilitas Fisik di Kota Batam." Jurnal HAM 11(1):27-37. doi: 10.30641/ ham.2020.11.27-37.
UNDRR. 2015. "Sendai Framework for Disaster Risk Reduction 2015-2030." United Nations Office for Disaster Risk Reduction. Retrieved (https://www.undrr.org/publication/send ai-framework-disaster-risk-reduction2015-2030).

UNHR 2020. "COVID-19 and the Rights of Persons with Disabilities: Guidance." United Nations Human Rights. Retrieved (https://www.ohchr.org/Documents/Iss ues/Disability/COVID-19_and_The_ Rights_of_Persons_with_Disabilities.pdf).

United Nations. 2016. "Toolkit on Disability for Africa." Department of Economic and Social Affairs. Retrieved (https://www.un.org/ development/desa/dspd/2016/11/toolkit -on-disability-for-africa-2/).

WHO. 2020a. "Disability Considerations during the COVID-19 Outbreak." World Health Organization. Retrieved (https://www. who.int/docs/default-source/documents/ disability/covid-19-disability-briefing.pdf).

WHO. 2020b. "Role of Community Engagement in Situations of Extensive Community Transmission of COVID-19." World Health Organization. Retrieved (https://www. who.int/publications/i/item/WPR-DSE2020-016).

Widjaja, Alia Harumdani, Winda Wijayanti, and Rizkisyabana Yulistyaputri. 2020. "Perlindungan Hak Penyandang Disabilitas dalam Memperoleh Pekerjaan dan Penghidupan yang Layak bagi Kemanusiaan." Jurnal Konstitusi 17(1): 197-223. doi: 10.31078/jk1719. 
This page has been intentionally left blank. 